Original Research Paper

\title{
Host Plant-Induced Susceptibility of Two-Spotted Spider Mite Tetranychus urticae (Acari: Tetranychidae) to Some Reduced-Risk Acaricides
}

\author{
Tarikul Islam \\ Department of Entomology, Bangladesh Agricultural University, Mymensingh, Bangladesh
}

\section{Article history}

Received: 13-11-2017

Revised: 31-03-2018

Accepted: 14-04-2018

Tel: +8801721204164

Email: tarikul.entom@bau.edu.bd

\begin{abstract}
The two-spotted spider mite Tetranychus urticae (Acari: Tetranychidae) is a cosmopolitan pest of a large number of host plants having extensive damage potential and the terrific ability of pesticide resistance. In the present study, spider mite population were reared continuously on the leaves of three susceptible host plants namely country bean (Phaseolus vulgaris L), papaya (Carica papaya L) and jute (Corchorus olitorius L) and their susceptibility to some reduced-risk acaricides were determined by leaf disc bioassay method. Abamectin was found to be the most toxic acaricide $\left(\mathrm{LC}_{50}\right.$ values were $0.432,0.342$ and $0.324 \mathrm{mg} \mathrm{L}^{-1}$ on the country bean, papaya and jute leaf discs respectively at $24 \mathrm{~h}$ after treatment application) which was followed by azadirachtin, emamectin benzoate, spinosad and hexythiazox respectively. For all the tested acaricides, toxicity increased proportionately with increasing time duration after treatment application. Moreover, spider mites reared on country bean leaves were comparatively less susceptible to all acaricides followed by mites reared on papaya and jute leaves respectively. Based on the present study, it might be inferred that host plants play a considerable role in the susceptibility of spider mites to acaricides and abamectin could be used as a puissant chemical for controlling spider mites.
\end{abstract}

Keywords: Host Plants, Toxicity, Bioassay, Tetranychus urticae, Acaricides

\section{Introduction}

The two-spotted spider mite Tetranychus urticae Koch (Acari: Tetranychidae) is a ubiquitous phytophagous pest that causes severe damage in a large number of crop plants, including fruits, vegetables and ornamentals (Stumpf et al., 2001; Migeon and Dorkeld, 2007). Spider mites feed by inserting their needle-like piercing-sucking mouthparts inside the plant tissue and they prefer to feed on the lower leaf surface (Attia et al., 2013). They also inject phytotoxic substances which lead to the destruction of chloroplast and produce necrotic spots on the leaf surface (Attia et al., 2013). Use of chemical pesticides is the most widely used measure for controlling spider mites. The excess use of acaricides against this pest in combination with its high reproductive potential, short life cycle and arrhenotokous mating system inevitably led to the development of resistance (Van Leeuwen et al., 2009). It is considered as the most resistant species among the arthropods based on the total number of pesticides to which it has developed resistance (Van Leeuwen et al., 2009).

Due to indiscriminate use of synthetic chemical pesticides and the associated problems of resistance and environmental pollution, there is a growing demand in developing more selective pesticides with novel modes of action, less environmental hazards and greater compatibility with natural enemies and bio-control agents (Steiner et al., 2011). At present, acaricide research is mainly focused on searching for bio-active substances from plants and microorganisms (Tedeschi et al., 2001; Attia et al., 2013) or development of other risk reduced acaricides with novel modes of action (Kumari et al., 2012). One of the most popular acaricides derived from the Azadirachta indica plant is azadirachtin which has been reported as a potent repellent, antifeedant, growth regulator and oviposition deterrent (Martínez-Villar et al., 2005). Hexythiazox is another commonly used mite growth regulator having multiple effects against spider mites, including ovicidal, nymphicidal and adulticidal actions (Kumari et al., 2017). 
In addition, different biorational pesticides like abamectin, emamectin benzoate and spinosad were reported to be effective against two-spotted spider mites, less persistent in soil and comparatively safe for beneficial organisms under field conditions (van Leeuwen et al., 2005; Ismail et al., 2007; Sun et al., 2010).

However, the susceptibility of a phytophagous pest to any pesticide may be considerably affected by its feeding on different host plants as the secondary plant metabolites induce the insect's detoxification enzymes which in turn influence the rapid metabolism of pesticides (Abro et al., 2013). Moreover, difference in susceptibility may be caused due to the variation in the amount of feeding by pest which is proportional to the amount of pesticide consumption. Understanding the effect of host plants on the susceptibility of pests is particularly important for a destructive polyphagous pest like Tetranychus urticae that has been reported to have 1100 host plant species belonging to almost 150 plant families (Grbić et al., 2011).

Although there are plenty of reports on the efficacy of different acaricides against Tetranychus urticae, variations in the susceptibility of spider mites due to their feeding on diverse host plants were rarely investigated. Therefore, the present study was planned to find out the toxicity of five reduced-risk acaricides viz. azadirachtin, abamectin, spinosad, hexythiazox and emamectin benzoate on the Tetranychus urticae population reared on three different susceptible host plants namely country bean (Phaseolus vulgaris L), Jute (Corchorus olitorius L) and papaya (Carica papaya L).

\section{Materials and Methods}

\section{Rearing of Two-Spotted Spider Mites}

The spider mites were collected from the research fields of Bangladesh Agricultural University, Mymensingh and were reared continuously on leaf discs $\left(\right.$ ca. $16 \mathrm{~cm}^{2}$ ) of country bean, jute and papaya. Leaf discs of bean, jute and papaya were kept on water-saturated polyurethane mats in plastic Petri dishes $(90 \mathrm{~mm}$ diameter, $20 \mathrm{~mm}$ depth). To eliminate the effect of any previous pesticide exposure, the fifth generation adult female spider mites were used in the bioassay. For obtaining fixed-age females, same aged eggs were separated from the mite culture and transferred on fresh leaf discs of the same plant. Rearing trays were always kept under controlled conditions at $25 \pm 1{ }^{\circ} \mathrm{C}$ temperature, $75 \pm 5 \% \mathrm{RH}$ and 16L: $8 \mathrm{Dh}$ photoperiod. After every four days, withered leaves were replaced with new fresh leaves of the same plant.

\section{Tested Reduced Risk Acaricides}

Five reduced risk acaricides were selected for the bioassay. There was a botanical called azadirachtin marketed as Bioneem plus 1 EC by Ispahani Biotech Ltd., Bangladesh and a mite growth regulator named hexythiazox marketed as Mite scavenger 10 EC by Eminence Chemical Industries Ltd. Other three pesticides were bacterial fermented derivatives namely spinosad marketed by Asia Trade International as Libsen 45SC, abamectin marketed by Haychem Bangladesh Ltd. as Ambush 1.8 EC and emamectin benzoate marketed by Haychem Bangladesh Ltd. as Suspend 5 SG. All the selected pesticides were collected from the local markets of Mymensingh, Bangladesh.

\section{Bioassay Procedures}

The toxicity of five reduced-risk pesticides against two-spotted spider mite, T. urticae was evaluated by leaf disc bioassay method on three different host leaves under laboratory conditions. In brief, leaf discs (ca. $16 \mathrm{~cm}^{2}$ ) using leaves of common bean, jute and papaya were prepared and placed on wet cotton pads in Petri dishes ( $90 \mathrm{~mm}$ diameter). Four to five-day-old mated females of $T$. urticae were placed on a new leaf disc (ca. $4 \times 4 \mathrm{~cm}^{2}$ ) and incubated for $24 \mathrm{~h}$. The acaricide solutions were prepared by diluting in water and five concentrations were used for each acaricide to determine the $\mathrm{LC}_{50}$ values. All the concentrations were selected based on preliminary concentration versus mortality experiments using a wide range of doses to find out the appropriate concentration range for the final bioassay (data not shown). One $\mathrm{ml}$ solution of each concentration of selected pesticides was applied directly to individual mite-infested leaf discs of bean, jute and papaya by using a hand operated micro-applicator sprayer (Burkard Scientific, UK). The control group was treated with distilled water only. There were three replicates for each treatment and 20 adult female mites were used in each replicate. After air drying, the mite-infested discs were kept at $25 \pm 2^{\circ} \mathrm{C}$ temperature, $80 \pm 5 \% \mathrm{RH}$ and $16 \mathrm{~L}$ : $8 \mathrm{D}$ photoperiod in an incubator. Mortality was recorded daily until the death of all the tested organisms.

\section{Statistical Analyses}

The mortality percentage of spider mites was corrected using Abbott's (1925) formula. The median lethal values $\left(\mathrm{LC}_{50}\right)$ were determined by probit analysis using ' $\mathrm{Ldp}$ line' software (http://www.ehabsoft.com/ldpline/). Statistical differences between $\mathrm{LC}_{50}$ estimates were determined by using a $95 \%$ CI for the ratio of two estimates (Robertson et al., 2007).

\section{Results}

Among the selected reduced-risk pesticides, abamectin showed the highest toxicity against Tetranychus urticae $\left(\mathrm{LC}_{50}\right.$ values were $0.432,0.234$ and $0.162 \mathrm{mg} \mathrm{L}^{-1}$ on country bean leaf; $0.342,0.216$ and $0.144 \mathrm{mg} \mathrm{L}^{-1}$ on papaya leaf; $0.324,0.198$ and $0.126 \mathrm{mg} \mathrm{L}^{-1}$ on jute leaf at 24,48 and $72 \mathrm{~h}$ after treatment application (HAT) respectively) which was followed by azadirachtin, emamectin benzoate, spinosad and hexythiazox respectively (Table 1). 
Table 1: Toxicity of selected reduced-risk acaricides against two-spotted spider mite, Tetranychus urticae on three different host plants

\begin{tabular}{|c|c|c|c|c|c|c|c|c|c|c|c|c|c|c|c|c|}
\hline \multirow[b]{2}{*}{$\begin{array}{l}\text { Tested } \\
\text { Acaricide }\end{array}$} & \multirow[b]{2}{*}{$\begin{array}{l}\text { Host } \\
\text { plant }\end{array}$} & \multicolumn{5}{|c|}{24 Hours } & \multicolumn{5}{|c|}{48 Hours } & \multicolumn{5}{|c|}{72 Hours } \\
\hline & & $\begin{array}{l}\mathrm{LC}_{50} \\
(\mathrm{mg} / \mathrm{L})\end{array}$ & $95 \% \mathrm{CI}$ & $\begin{array}{l}\text { Slope } \pm \\
\text { SE }\end{array}$ & $x^{2}$ & df & $\begin{array}{l}\mathrm{LC}_{50} \\
(\mathrm{mg} / \mathrm{L})\end{array}$ & $95 \% \mathrm{CI}$ & $\begin{array}{l}\text { Slope } \pm \\
\text { SE }\end{array}$ & $x^{2}$ & df & $\begin{array}{l}\mathrm{LC}_{50} \\
(\mathrm{mg} / \mathrm{L})\end{array}$ & $95 \% \mathrm{CI}$ & $\begin{array}{l}\text { Slope } \pm \\
\text { SE }\end{array}$ & $x^{2}$ & $\mathrm{df}$ \\
\hline \multirow[t]{3}{*}{ Azadirachtin } & $\begin{array}{l}\text { Country } \\
\text { bean }\end{array}$ & 20.10 & $14.60-56.80$ & $\begin{array}{l}1.91 \pm \\
0.587\end{array}$ & 0.084 & 3 & 12.90 & $9.80-22.60$ & $\begin{array}{l}1.734 \pm \\
0.542\end{array}$ & 0.793 & 3 & 8.80 & $6.0-11.40$ & $\begin{array}{l}1.90 \pm \\
0.539\end{array}$ & 1.404 & 3 \\
\hline & Papaya & 16.90 & $12.90-33.50$ & $\begin{array}{l}1.993 \pm \\
0.572\end{array}$ & 0.285 & 3 & 11.40 & $8.70-16.50$ & $\begin{array}{l}1.879 \pm \\
0.542\end{array}$ & 1.509 & 3 & 7.20 & $4.70-9.10$ & $\begin{array}{l}2.111 \pm \\
0.549\end{array}$ & 0.838 & 3 \\
\hline & Jute & 14.90 & $11.50-27.30$ & $\begin{array}{l}1.898 \pm \\
0.556\end{array}$ & 0.129 & 3 & 9.30 & $6.40-12.60$ & $\begin{array}{l}1.754 \pm \\
0.536\end{array}$ & 0.649 & 3 & 6.80 & $4.60-8.40$ & $\begin{array}{l}2.372 \pm \\
0.562\end{array}$ & 1.707 & 3 \\
\hline \multirow[t]{3}{*}{ Spinosad } & $\begin{array}{l}\text { Country } \\
\text { bean }\end{array}$ & 32.40 & $21.50-46.75$ & $\begin{array}{l}1.524 \pm \\
0.471\end{array}$ & 0.645 & 3 & 20.70 & $12.45-26.65$ & $\begin{array}{l}1.455 \pm \\
0.435\end{array}$ & 0.626 & 3 & 16.20 & $7.65-24.30$ & $\begin{array}{l}1.50 \pm \\
0.434\end{array}$ & 0.258 & 3 \\
\hline & Papaya & 29.70 & $19.80-43.65$ & $\begin{array}{l}1.455 \pm \\
0.435\end{array}$ & 0.626 & 3 & 18.00 & $9.45-23.85$ & $\begin{array}{l}1.694 \pm \\
0.439\end{array}$ & 0.825 & 3 & 13.05 & $7.20-17.55$ & $\begin{array}{l}2.122 \pm \\
0.472\end{array}$ & 2.379 & 3 \\
\hline & Jute & 27.90 & $18.00-40.05$ & $\begin{array}{l}1.474 \pm \\
0.435\end{array}$ & 0.479 & 3 & 17.10 & $9.45-22.95$ & $\begin{array}{l}1.770 \pm \\
0.442\end{array}$ & 1.186 & 3 & 14.40 & $8.55-18.90$ & $\begin{array}{l}2.224 \pm \\
0.470\end{array}$ & 3.076 & 3 \\
\hline \multirow[t]{3}{*}{ Hexythiazox } & $\begin{array}{l}\text { Country } \\
\text { bean }\end{array}$ & 132.0 & $119.0-142.0$ & $\begin{array}{l}1.504 \pm \\
0.438\end{array}$ & 0.153 & 3 & 96.0 & $88.0-120.0$ & $\begin{array}{l}1.629 \pm \\
0.436\end{array}$ & 0.146 & 3 & 76.0 & $68.0-81.0$ & $\begin{array}{l}1.865 \pm \\
0.443\end{array}$ & 1.391 & 3 \\
\hline & Papaya & 124.0 & $117.0-133.0$ & $\begin{array}{l}1.643 \pm \\
0.439\end{array}$ & 0.029 & 3 & 91.0 & $82.0-116.0$ & $\begin{array}{l}1.683 \pm \\
0.438\end{array}$ & 0.405 & 3 & 70.0 & $63.0-77.0$ & $\begin{array}{l}2.056 \pm \\
0.464\end{array}$ & 1.389 & 3 \\
\hline & Jute & 122.0 & $115.0-130.0$ & $\begin{array}{l}1.674 \pm \\
0.438\end{array}$ & 0.251 & 3 & 85.0 & $73.0-110.0$ & $\begin{array}{l}1.955 \pm \\
0.446\end{array}$ & 1.40 & 3 & 68.0 & $60.0-75.0$ & $\begin{array}{l}2.251 \pm \\
0.474\end{array}$ & 2.012 & 3 \\
\hline \multirow[t]{3}{*}{ Abamectin } & $\begin{array}{l}\text { Country } \\
\text { bean }\end{array}$ & 0.432 & $0.306-0.612$ & $\begin{array}{l}1.615 \pm \\
0.438\end{array}$ & 0.728 & 3 & 0.234 & $0.108-0.324$ & $\begin{array}{l}1.655 \pm \\
0.443\end{array}$ & 0.952 & 3 & 0.162 & $0.052-0.234$ & $\begin{array}{l}1.861 \pm \\
0.482\end{array}$ & 2.046 & 3 \\
\hline & Papaya & 0.342 & $0.216-0.468$ & $\begin{array}{l}1.629 \pm \\
0.436\end{array}$ & 0.146 & 3 & 0.216 & $0.090-0.306$ & $\begin{array}{l}1.620 \pm \\
0.445\end{array}$ & 1.532 & 3 & 0.144 & $0.036-0.216$ & $\begin{array}{l}1.773 \pm \\
0.477\end{array}$ & 2.352 & 3 \\
\hline & Jute & 0.324 & $0.180-0.432$ & $\begin{array}{l}1.683 \pm \\
0.438\end{array}$ & 0.405 & 3 & 0.198 & $0.108-0.288$ & $\begin{array}{l}1.930 \pm \\
0.461\end{array}$ & 1.718 & 3 & 0.126 & $0.022-0.182$ & $\begin{array}{l}1.888 \pm \\
0.472\end{array}$ & 1.082 & 3 \\
\hline \multirow[t]{3}{*}{$\begin{array}{l}\text { Emamectin } \\
\text { benzoate }\end{array}$} & $\begin{array}{l}\text { Country } \\
\text { bean }\end{array}$ & 26.0 & $16.5-35.5$ & $\begin{array}{l}1.420 \pm \\
0.439\end{array}$ & 0.690 & 3 & 20.0 & $11.0-24.5$ & $\begin{array}{l}1.810 \pm \\
0.441\end{array}$ & 0.208 & 3 & 12.0 & $6.0-18.5$ & $\begin{array}{l}1.810 \pm \\
0.441\end{array}$ & 0.208 & 3 \\
\hline & Papaya & 24.0 & $14.5-32.5$ & $\begin{array}{l}1.629 \pm \\
0.436\end{array}$ & 0.146 & 3 & 16.0 & $8.0-21.50$ & $\begin{array}{l}1.823 \pm \\
0.451\end{array}$ & 1.294 & 3 & 10.0 & $5.0-15.50$ & $\begin{array}{l}1.823 \pm \\
0.451\end{array}$ & 1.294 & 3 \\
\hline & Jute & 22.0 & $12.5-29.5$ & $\begin{array}{l}1.683 \pm \\
0.438\end{array}$ & 0.406 & 3 & 15.5 & $9.5-20.0$ & $\begin{array}{l}2.362 \pm \\
0.481\end{array}$ & 2.171 & 3 & 8.5 & $3.5-13.50$ & $\begin{array}{l}2.362 \pm \\
0.481\end{array}$ & 2.171 & 3 \\
\hline
\end{tabular}

Spider mites population were moderately susceptible to azadirachtin, emamectin benzoate and spinosad, however, they showed the lowest susceptibility to the mite growth regulator hexythiazox $\left(\mathrm{LC}_{50}\right.$ values were 132, 96 and $76 \mathrm{mg} \mathrm{L}^{-1}$ on country bean leaf; 124, 91 and $70 \mathrm{mg} \mathrm{L}^{-1}$ on papaya leaf; 122,85 and $68 \mathrm{mg} \mathrm{L}^{-1}$ on jute leaf at 24, 48 and 72 HAT respectively). For all the treatments, toxicity was clearly time-dependent i.e., toxicity increased proportionately with time duration. Interestingly, the susceptibility of Tetranychus urticae to the selected pesticides was significantly influenced by the host plants. It was observed that the spider mites reared and fed on country bean leaves were much less susceptible to all pesticides which were followed by the mites fed on papaya and jute leaves respectively. For example, in case of azadirachtin, $\mathrm{LC}_{50}$ values were $20.10,16.90$ and $14.90 \mathrm{mg} \mathrm{L}^{-1}$ at 24 HAT on the country bean, papaya and jute leaves respectively. Similar trends were observed for all other pesticides at a definite time after treatment application (Table 1).

\section{Discussion}

Spider mites are highly mobile and polyphagous pest, which necessitate the use of chemical pesticides more frequently for successful control (Dekeyser, 2005; Kumari et al., 2012). In the present study, we evaluated five reduced risk acaricides against two-spotted spider mites on the leaf discs of country bean, papaya and jute plants and determined the median lethal concentrations. The experimental results revealed that abamectin was most effective in controlling spider mites having lowest $\mathrm{LC}_{50}$ values. Abamectin is a biorational molecule derived from the fermentation of the soil bacterium Streptomyces avermitilis which had been reported as the most widely used acaricide around the world (Ismail et al., 2007). It is a neuro-active compound which mainly works as a chloride channel activator of insects' nervous system (Dekeyser, 2005). Kumari et al. (2017) reported abamectin as the most toxic acaricide against the adult spider mites with lowest $\mathrm{LC}_{50}$ value $(0.39 \mathrm{ppm})$ on bean leaf disc at 24 HAT, which is slightly lower than our estimated value $\left(0.432 \mathrm{mg} \mathrm{L}^{-1}\right)$ on the same leaf disc. We found azadirachtin as the second most toxic compound against spider mite with an $\mathrm{LC}_{50}$ value of $14.90 \mathrm{mg} \mathrm{L}^{-1}$ on jute leaf at 24 HAT which is lower than the estimated value (64 ppm) by Martínez-Villar et al. (2005).

Moreover, our findings are somewhat contradictory with Sun et al. (2010), who reported emamectin benzoate to be more toxic than abamectin against Tetranychus urticae in both laboratory and fields trials. We found abamectin to be approximately 60, 70 and 68 times more toxic than emamectin benzoate on the bean, papaya and jute leaves respectively at 24 HAT. There was conflicting evidence about the acaricidal activity of spinosad against spider mites, however, our results confirmed its toxicity against Tetraychus urticae, although our estimated median lethal values (32.40, 29.70 and 
$27.90 \mathrm{mg} \mathrm{L}^{-1}$ on bean, papaya and jute leaf disc respectively at $24 \mathrm{HAT}$ ) were slightly higher than $\mathrm{LC}_{50}$ value $\left(24 \mathrm{mg} \mathrm{L}^{-1}\right)$ reported by Ismail et al. (2007) on sweet potato leaf disc. Previous works showed that spinosad mainly works on the activation sites of the nicotinic acetylcholine receptors in the nervous system of insects and also affects the functioning of GABA receptor (Orr et al., 2009).

Though hexythiazox has been reported as a mite growth regulator having multiple effects against spider mites, including ovicidal, nymphicidal and adulticidal actions (Kumari et al., 2017), in the current study, it was found least toxic acaricide against spider mites. Hexythiazox was approximately 306, 363 and 377 times less toxic on bean, papaya and jute leaf discs respectively at $24 \mathrm{HAT}$ compared to the most effective acaricide abamectin. However, the calculated $\mathrm{LC}_{50}$ values of hexythiazox $(132,124$ and $122 \mathrm{mg} / \mathrm{L}$ on bean, papaya and jute leaf discs respectively at 24 HAT) in the present study were much lower than the previously estimated values of $527.45 \mathrm{ppm}$ by Alzoubi and Cobanoglu (2008) and $277.47 \mathrm{ppm}$ by Kumari et al. (2017). This reduced toxicity of hexythiazox against Tetranychus urticae might be an indication of spider mites resistance against this widely used acaricide (Vassiliou and Kitsis, 2013).

We also observed that there was significant variation in the toxicity of pesticides against spider mites on three different leaf discs. Susceptibility of spider mites was higher when they were reared on jute leaves followed by mites reared on papaya and country bean leaves respectively, although, the extent of increased susceptibility varied depending on pesticides. Many factors could contribute to this variation under field conditions; nevertheless, we conducted bioassay on the leaf discs under completely controlled conditions which indicate that the host chemistry is one of the most important contributing factors for the difference in $\mathrm{LC}_{50}$ values. Such host plant induced variation of the toxicity of pesticides against spider mites was previously reported by Ibrahim (2009) and Yang et al. (2001). It is hypothesized that such difference in susceptibility of pesticides might be related to the nutritive state of the spider mites. Tetranychus urticae faced with a novel host may not feed, or not feed as much, as spider mites on more familiar host plants. This could cause reduced general esterase activity in the beginning and associated changes in susceptibility to pesticides, in mites on novel host plants (Yang et al., 2001).

Moreover, different allelochemicals and detoxifying enzymes associated with the host plants may have a considerable impact on the immunity of spider mites which may ultimately affect the toxicity of pesticides against spider mites. Dermauw et al. (2013) reported that feeding on alternative hosts can change the activity of spider mite detoxification enzymes and reduce the acute toxicity of some selected acaricides. Yang et al. (2001) found that susceptibility of spider mites feeding on cucumber was significantly higher to synthetic pyrethroids and organophosphates compared to the mites reared on lima bean and maize plants. He reported that host plant-induced changes in general esterase activity, possibly in combination with Glutathione $S$-transferase (GST) activity, in Tetranychus urticae appeared to be inversely related to and dubiously accountable for, changes in susceptibility of two-spotted spider mite to dimethoate and synthetic pyrethroid pesticides. However, more research work is needed for the better understanding of the biochemical interactions between Tetranychus urticae and its host plants, which are affecting the toxicity of pesticides against spider mite population.

\section{Conclusion}

Based on our experimental results, it might be concluded that feeding on diverse hosts significantly alters the susceptibility of Tetranychus urticae to different pesticides which need to be addressed for the effective management of spider mites. Moreover, abamectin could be used successfully for controlling Tetranychus urticae population irrespective of their host plants.

\section{Acknowledgment}

The author is thankful to Bangladesh Agricultural University Research System (BAURES) for the financial support.

\section{Disclosure Statement}

No potential conflict of interest was reported by the author.

\section{Ethics}

The author declares that the manuscript is based on original research work and it has not been published or submitted for publication elsewhere.

\section{References}

Abbott, S.W., 1925. A method of computing the effectiveness of an insecticide. J. Economic Entomol., 18: 265-267. DOI: 10.1093/jee/18.2.265a

Abro, G.H., T.S. Syed, A.N. Kalhoro, G.H. Sheikh and M.S. Awan et al., 2013. Insecticides for control of the diamondback moth, Plutellaxylostella (L.) (Lepidoptera: Plutellidae) in Pakistan and factors that affect their toxicity. Crop Protect., 52: 91-96. DOI: 10.1016/j.cropro.2013.05.017 
Alzoubi, S. and S. Cobanoglu, 2008. Toxicity of some pesticides against Tetranychus urticae Koch and its predatory mites under laboratory conditions. Am. Eurasian J. Agric. Environ. Sci., 3: 30-37.

Attia, S., K.L. Grissa, G. Lognay, E. Bitume and T. Hance et al., 2013. A review of the major biological approaches to control the worldwide pest Tetranychus urticae (Acari: Tetranychidae) with special reference to natural pesticides. J. Pest Sci., 86: 361-386. DOI: 10.1007/s10340-013-0503-0

Dekeyser, M.A., 2005. Acaricide mode of action. Pest Manage. Sci., 61: 103-110. DOI: 10.1002/ps.994

Dermauw, W., N. Wybouw, S. Rombauts, B. Menten and J. Vontas et al., 2013. A link between host plant adaptation and pesticide resistance in the polyphagous spider mite Tetranychus urticae. Proc. Nat. Acad. Sci., 110: E113-E122. DOI: $10.1073 /$ pnas. 1213214110

Grbić, M., T. Van Leeuwen, R.M. Clark, S. Rombauts and P. Rouzé et al., 2011. The genome of Tetranychus urticae reveals herbivorous pest adaptations. Nature, 479: 487-487. DOI: 10.1038 /nature 10640

Ibrahim, M.M.S., 2009. Effect of the host plant on susceptibility of the two-spotted spider mite, Tetranychus urticae Koch, (Acari: Tetranychidae) to some acaricides. J. Agric. Sci. Mansoura Univ., 34: 10735-10744.

Ismail, M.S., M.F. Soliman, M.H. El Naggar and M.M. Ghallab, 2007. Acaricidal activity of spinosad and abamectin against two-spotted spider mites. Exp. Applied Acarol., 43: 129-135. DOI: $10.1007 / \mathrm{s} 10493-007-9108-8$

Kumari, A., A. Kumar, D.K. Tewary and G. Nadda, 2012. Field evaluation of bifenazate (Acramite $50 \mathrm{WP}$ ) for control of tea mites. Munis Entomol. Zool. J., 7: 780-786.

Kumari, S., U. Chauhan, A. Kumari and G. Nadda, 2017. Comparative toxicities of novel and conventional acaricides against different stages of Tetranychus urticae Koch (Acarina: Tetranychidae). J. Saudi Society Agric. Sci., 16: 191-196. DOI: $10.1016 /$ j.jssas.2015.06.003

Martínez-Villar, E., F.J. Sáenz-De-Cabezón, F. MorenoGrijalba, V. Marco and I. Pérez-Moreno, 2005. Effects of azadirachtin on the two-spotted spider mite, Tetranychus urticae (Acari: Tetranychidae). Exp. Applied Acarol., 35: 2-15. DOI: $10.1007 / \mathrm{s} 10493-004-5082-6$

Migeon, A. and F. Dorkeld, 2007. Spider Mites Web: A comprehensive database for the Tetranychidae.
Orr, N., A.J. Shaffner, K. Richey and G.D. Crouse, 2009. Novel mode of action of spinosad: Receptor binding studies demonstrating lack of interaction with known insecticidal target sites. Pesticide Biochem. Physiol., 95: 1-5. DOI: 10.1016/j.pestbp.2009.04.009

Robertson, J.L., R.M. Russell, N.E. Savin and H.K. Preisler, 2007. Pesticide Bioassays with Arthropods. 1st Edn., CRC Press, London, pp: 224.

Steiner, M.Y., L.J. Spohr and S. Goodwin, 2011. Impact of two formulations of the acaricide bifenazate on the spider mite predator Phytoseiulus persimilisAthiasHenriot (Acari: Phytoseiidae). Australian J. Entomol., 50: 99-105. DOI: $10.1111 / \mathrm{j} .1440-6055.2010 .00789 . x$

Stumpf, N., C.P.W. Zebitz, W. Kraus, G.D. Moores and R. Nauen, 2001. Resistance to organophosphates and biochemical genotyping of Acetylcholinesterases in Tetranychus urticae (Acari: Tetranychidae). Pest Biochem. Physiol., 69: 131-142. DOI: $10.1006 /$ pest.2000.2516

Sun, R.H., Y. Zhang, A.H. Li, X.J. Li and G.F. Wang, 2010. Comparison among efficacy of emamectin benzoate and abamectin to two apple pest mites [J]. Agrochemicals, 4: 020.

Tedeschi, A., A. Alma and L. Tavella, 2001. Side-effects of three neem (Azadirachtaindica A. Juss) products on the predator Macrolophuscaliginosus Wagner (Het., Miridae). J. Applied Entomol., 125: 397-402. DOI: 10.1046/j.1439-0418.2001.00563.x

Van Leeuwen, T., T. Vontas and A. Tsagkarakou, 2009. Mechanisms of acaricide resistance in the two-spotted spider mite Tetranychus urticae. Biorational control of arthropod pests, Springer, Dordrecht, pp: 347-393.

Van Leeuwen, T., W. Dermauw, M. Van De Veire and L. Tirry, 2005. Systemic use of spinosad to control the two-spotted spider mite (Acari: Tetranychidae) on tomatoes grown in rockwool. Exp. Applied Acarol., 37: 93-105. DOI: 10.1007/s10493-005-0139-8

Vassiliou, V.A. and P. Kitsis, 2013. Acaricide resistance in Tetranychus urticae (Acari: Tetranychidae) populations from Cyprus. J. Economic Entomol., 106: 1848-1854. DOI: 10.1603/EC12369

Yang, X., D.C. Margolies, K.Y. Zhu and L.L. Buschman, 2001. Host plant-induced changes in detoxification enzymes and susceptibility to pesticides in the twospotted spider mite (Acari: Tetranychidae). J. Economic Entomol., 94: 381-387.

DOI: $10.1603 / 0022-0493-94.2 .381$ 